\title{
Zirconium Zr 89 DFO-MSTP2109A
}

National Cancer Institute

\section{Source}

National Cancer Institute. Zirconium Zr 89 DFO-MSTP2109A. NCI Thesaurus. Code C104420.

A radioimmunoconjug ate composed of the radioisotope zirconium $\mathrm{Zr} 89$ conjug ated to an antibody that targets six transmembrane epithelial antigen of the prostate 1 (STEAP1) that can potentially be used as a prostate cancer tracer during positron emission tomography (PET). Upon administration of zirconium Zr 89 DFO-MST P2109A, the antibody moiety DFO-MST P2109A binds to STEAP1 on prostate cancer cells. In turn, Zr 89 allows for the visualization of those cells using PET. STEAP1, a six-transmembrane domain protein, is overexpressed on the surface of prostate cancer cells. 